\title{
INTEGRITAS DIRI \\ SEBAGAI KARAKTER PELAYAN TUHAN
}

\author{
Pdt. Peter Anggu \\ Intisari
}

Seorang pelayan ideal adalah seorang pelayan yang memiliki karakter-karakter luhur dan mulia, sehingga ia berwibawa dan menjadi saluran berkat Allah bagi orang lain.

Gereja sedang merindukan pelayan-pelayan yang mempunyai integritas diri untuk menjadi teladan dalam pengabdian dan ketaatan kepada Tuhan.

\section{Pendahuluan}

Kamus Umum Bahasa Indonesia mendefinisikan Integritas sebagai suatu "mutu, sifat atau keadaan yang menunjukkan kesatuan yang utuh, sehingga memiliki potensi dan kemampuan yang memancarkan kewibawaan"1 Definisi ini mengandung makna bahwa seseorang yang memiliki integritas adalah orang yang berkwalitas, berkepribadian utuh dan berwibawa. Singkatnya, seorang yang berkepribadian utuh dan berwibawa yang dibuktikan dengan persisnya sama apa yang diucapkan bibir dengan apa yang ada di dalam hati, atau apa yang diucapkan sama dengan apa yang dilakukan secara konsisten, meskipun dalam situasi dan keadaan yang berpancaroba. Misalnya, seorang penatua, harus mampu menerima dan percaya diri apa adanya sebagai seorang penatua, yang berpikiran penatua, berucapan penatua, bertingkah dan berperilaku penatua, sehingga ia dapat diterima dan dipercayai serta dihargai sebagai seorang penatua oleh isteri atau suami dan anak-anaknya, oleh tetangga, oleh jemaat dan masyarakat luas entah di rumah, di kantor, di jemaat dan di mana saja ia berada. John C. Maxweel, seorang pendeta dan penulis terkenal dalam bukunya Mengembangkan Kepemimpinan di dalam Diri Anda menyatakan "Seorang yang punya integritas tidak membagi loyalitas (sikap mendua), atau pun dia hanya berpura-pura (itu kemunafikan). Orang yang memiliki integritas adalah orang utuh; mereka bisa diidentifikasikan dengan kesatuan pikirannya. Orang yang memiliki integritas, tidak punya apa pun untuk disembunyikan dan tidak punya apa pun untuk ditakuti."

Jadi, integritas seorang pelayan adalah kondisi atau keadaan yang menunjukkan sikap yang asli dan tulen, tanpa berpura-pura dan sembunyisembunyi sehingga ia dihormati dan disegani, baik oleh kawan maupun lawan, karena padanya tidak didapati suatu noda yang mengurangi harga diri dan wibawanya.

\section{Pentingnya Integritas}

Sekarang kita hidup dalam satu masa yang sukar atau sulit karena ulah manusia sendiri (2 Tim. 3:1-5). Skandal atau perbuatan yang memalukan, dan menurunkan martabat serta moral seseorang dalam berbagai bentuk telah dan sedang terjadi di mana-mana, baik yang sembunyi-sembunyi maupun yang terangterangan dengan cara korupsi, persekongkolan dan penyuapan, pembohongan dan pemalsuan, perselingkuhan, perzinahan, dsb. Skandal itu telah menodai jabatan-jabatan terhormat dalam masyarakat seperti kepala negara, anggota ek- 
sekutif dan legislatif, tokoh-tokoh masyarakat, termasuk pendidik dan rohaniawan yang dianggap sebagai pemangku jabatan suci seperti pendeta, dsb. Jika kalangan atas yang terhormat telah terserang dan berantakan, apalagi di kalangan biasa, seperti pegawai negeri dan swasta, pengusaha, selebritis, tukang sapu, beragama maupun tidak, tidak Kristen maupun Kristen, baik laki-laki maupun perempuan, baik anak-anak maupun yang sudah kakek-kakek dan nenek-nenek.

Jika kondisi habis-habisan ini ditelusuri kasus per kasus, maka ternyata akar permasalahannya akan bermuara pada rentrannya integritas individu yang bersangkutan. Di sinilah letak pentingnya integritas sebagai faktor yang sangat menentukan dalam seluruh aspek kehidupan manusia. Sangat tepat apa yang Tuhan Yesus katakan, "Jika garam itu telah menjadi tawar, dengan apakah ia diasinkan? Tidak ada lagi gunanya selain dibuang dan dinjak-injak orang" (Mat. 5:13). Kalau seorang pemimpin sudah tidak memiliki integritas, apa gunanya lagi ia bertahan dan mempertahankan dirinya sebagai pemimpin. Kalau seorang pelayan Tuhan apa pun namanya entah pendeta, penatua, majelis, dsb. sudah ternoda, bagaimanakah lagi ia bisa dipertahankan sebagai pelayan Tuhan Mahaagung itu. Apakah artinya kalau seorang pendeta atau majelis gereja yang setiap hari Minggu berkhotbah dari mimbar gereja, tetapi integritasnya telah retak dan hancur melalui ketamakan, perselisihan dan perselingkuhan? Betapa pentingnya integritas itu karena harga diri, kepercayaan, pengaruh yang tinggi, prestasi dan reputasi yang kuat ditentukan olehnya. Integritas yang rusak, bagaikan pohon besar yang akar-akarnya telah busuk, cepat atau lambat akan tumbang dan hancur.

Secara panjang lebar John C. Maxweel yang menempatkan integritas sebagai faktor kepemimpinan yang paling penting, yang mengemukakan tujuh alasan mengapa integritas itu paling penting bagi seseorang. ${ }^{3}$

Pertama, Integritas adalah dasar keper-cayaan. Pengaruh kehidupan mengalir melalui kepercayaan.

Kedua, Integritas mempunyai nilai peng-aruh yang tinggi. Penelitian menunjukkan bahwa integritas adalah kwalitas manusia yang paling diperlukan bagi sukses dalam bisnis.

Ketiga, Integritas adalah ukuran dari standar yang tinggi. Standar pemimpin harus lebih tinggi dari pada para pengikutnya. Kalau watak seorang pemimpin rendah, maka standar kepemimpinan itu pasti rendah pula.

Keempat, Integritas menghasilkan reputasi yang kuat, tidak pernah mengecewakan.

Kelima, Integritas adalah keteladanan yang harus dimulai dari diri yang akan mengalir dan menular kepada orang lain.

Keenam, Integritas lebih dari kepintaran dan kemampuan, meskipun semua itu diperlukan.

Ketujuh, Integritas adalah prestasi yang dicapai dengan susah payah, bukan dengan bermasa bodoh.

\section{Faktor-Faktor Pemicu Disintegritas Diri}

Jika perjalanan hidup ini diandaikan suatu perjuangan, maka ada titiktitik rawan yang perlu diwaspadai karena di sana biasa terjadi konflik dan kecelakaan yang sering menelan korban yang tidak diinginkan. Dari pengalaman dan pemantauan, kita dapati sejumlah kondisi yang biasanya merupakan faktor pemicu terjadinya disintegrasi atau hancurnya wibawa dan kepercayaan terhadap seorang pelayan Tuhan. 


\section{Ketidakpuasan}

Perasaan tidak puas rupanya adalah penyakit tertua yang konon bermula di Surga, ketika sejumlah malaikat mengadakan pemberontakan karena tidak puas dan tidak taat pada batas-batas kekuasan yang telah ada pada mereka (Yud. 1:6).

Pada dasarnya, ketidakpuasan terjadi karena beberapa sebab antara lain:

Pertama, Tidak puas terhadap diri sendiri. Ketidakpuasan ini disebabkan karena adanya konsep diri yang salah. Biasanya orang yang mempunyai konsep diri yang salah, selalu berusaha membandingkan dirinya dengan orang lain dan dalam pembandingan itu kebanyakan yang negatif diarahkan pada diri sendiri yang selalu menggelisahkan orang itu.

Kedua, Ketidakpuasan atas perlakuan orang lain terhadap diri sendiri. Ketidakpuasan ini adalah reaksi terhadap kata-kata dan perlakuan orang yang dianggap merendahkan, melecehkan, atau menginjak-injak hak asasinya. Ketidakpuasan semacam ini biasanya gampang menimbulkan ketersinggungan, kekecewaan, kemarahan, caci maki, pertengkaran dan permusuhan yang pada sisi lain bermakna penghancuran wibawa dan harga diri sendiri.

Ketiga, Ketidakpuasan yang tak terkendali. Yaitu perasaan yang tidak pernah merasa puas dengan apa yang ada, yang bagaikan samudera yang tidak pernah merasa penuh meski hujan dan banjir terus mengalir ke sana. Atau bagaikan orang yang minum air garam, makin banyak minum makin merasa haus. Punya satu mau dua, punya dua mau empat dst. Betapa banyak orang termasuk yang disebut hamba-hamba baik yang hancur karena keserakahan dan keinginan yang tak terkendali.

\section{Kecerobohan}

Kecerobohan adalah tindakan yang tidak melalui perhitungan lebih dahulu.
Hal ini biasanya terjadi pada orang yang suka memandang enteng masalah dan tidak memikirkan resiko sebagai akibat perbuatan itu. Seorang guru besar, teman saya memilih mundur sebagai dosen pegawai negeri karena telah diunggulkan sebagai salah seorang calon legeslatif di pusat, tetapi akhirnya tidak jadi dan sudah terlanjur berhenti sebagai dosen. Akhirnya stroke dan tidak pernah sembuh sampai ia meninggal. Hati-hati karena banyak jalan yang disangka menuju ke Surga, tetapi ujungnya membawa ke neraka.

\section{Kurang Percaya Diri}

Kurang percaya diri (kurang PD) sama dengan tidak menghargai diri sendiri. Hal ini disebabkan oleh beberapa hal:

Pertama, Faktor budaya. Karena memang leluhurnya orang yang biasa disuruh-suruh dulu sehingga seumur hidupnya selalu merasa minder meskipun ia seorang hamba Tuhan.

Kedua, Karena pengalaman yang mengecewakan. Mungkin karena pernah mencoba lalu gagal; Melayangkan surat cinta pada seorang gadis dan dibalas dengan penghinaan, akhirnya seumur hidup sudah tidak mau bangkit. Orang yang tidak percaya diri sulit untuk bisa dipercaya. "Jangan mengharapkan orang lain akan menghargai Anda jika Anda sendiri tidak menghargai dirimu." Pandanglah kepada Yesus karena Yesus "selalu mengucapkan kata-kata yang penuh cinta kasih, kuat dan meyakinkan tentang dirinya sendiri. ...Yesus tidak pernah menghina diri-Nya sendiri" ${ }^{4}$. Artinya adalah contoh dari keyakinan akan dirinya sendiri. Apakah untungnya bagi seorang sarjana yang pintar, tetapi ia kehilangan dirinya sendiri?

\section{Emosi yang tak Terkendali}

Pada dasarnya emosi adalah pemberian Tuhan yang harus diterima 
dengan penuh syukur, karena dengan emosi kita dapat mengadakan apresiasi yang tinggi dalam hidup ini. Namun emosi yang tak terkendali akan meruntuhkan integritas seseorang. Emosi yang tak terkendali dapat menghasilkan tindakantindakan kasar dan perlakuan yang sewenang-wenang, yang tidak patut dilakukan oleh seorang pelayan Tuhan. Saya pernah mendengar pelayan-pelayan Tuhan babak belur pada waktu mengikuti suatu persidangan gerejawi akibat emosi peserta rapat yang tak terkendali.

\section{Pembangkangan}

Pembangkangan adalah sikap dan tindakan kepala batu, yang tidak mau taat kepada peraturan dan ketentuan-ketentuan yang berlaku. Saya mengenal seorang hamba Tuhan yang oleh sinodenya akan dipindahkan ke Palembang, namun dengan alasan ini dan itu ia tidak bersedia. Akhirnya ia terpaksa dipensiun secara dini. Untung masih dipensiunkan karena seharusnya pembangkang ganjarannya ialah dipecat. Saya mendengar di beberapa tempat pernah terjadi bahwa penjabatan yang membangkang mempengaruhi anggota-anggota jemaat untuk menjadi tamengnya, sehingga akibatnya jemaat berpihak-pihak dan akhirnya perpecahan tidak terhindari lagi. Dimanakah integritas pelayan dalam kasus sedemikian ini?

\section{Kecurangan}

Kecurangan adalah perbuatan culas dan tidak jujur, yaitu penipuan yang dilakukan seolah-olah benar, tetapi penuh kebohongan dan kepalsuan, yaitu lain di mulut lain di hati. Betapa banyaknya Ananias dan Safira masa kini yang sering tampil memberi kesaksian dari apa yang sesungguhnya tidak sesuai dengan perbuatannya. Akhir-akhir ini banyak kasus pemalsuan-pemalsuan ijazah, pemalsuan tanda tangan, pemalsuan umur, pemalsuan dokumen, dsb.

\section{Ingkar Janji}

Ingkar janji hampir sama dengan kecurangan, hanya saja bahwa ada kalanya ingkar janji terjadi karena terdesak. Masalahnya ialah bahwa biasanya berjanji itu gampang, tetapi bilamana masa janji itu tiba maka timbullah masalah. Karena itu, lebih baik tidak berjanji daripada berjanji lalu ingkar. Bisa dibayangkan jika seorang pelayan dikejar-kejar oleh utang janji yang tak kunjung dipenuhi.

\section{Perselingkuhan}

Percaya atau tidak bahwa zaman ini adalah zaman perselingkuhan. Pertanyannya ialah mengapa hal itu terjadi demikian? Ada beberapa kemungkinan,

Pertama, Nilai moral termasuk kerohanian sudah sangat tipis. Manusia sudah tidak takut kepada Tuhan. mudah.

Kedua, Faktor penunjangnya sangat

Ketiga, Ketidakpuasan tempat pelarian.

Keempat, Sekedar iseng.

Kelima, Sangsi kurang memadai.

\section{Konflik}

Saya tidak lupa ketika saya dalam suatu percakapan di rumah seorang anggota jemaat, seorang teman nyelonong berkata, "Saya bingung pak, karena di mana-mana terjadi kekacauan, di gereja dan yang lebih parah lagi ialah bahwa yang menciptakan konflik dan pertentangan serta kekacauan itu adalah para pemimpin gereja." Sebagai seorang hamba Tuhan. saya malu karena penyataan itu disertai bukti yang tidak jauh dari kami pada saat itu. Konflik adalah salah satu pemicu terjadinya disintegritas hamba Tuhan yang sangat perlu diwaspadai.

\section{Lupa Diri}

Lupa diri adalah kondisi yang terjadi ketika seseorang berada pada suatu 
situasi yang dianggap luar biasa, sehingga hilang kesadaran dirinya. Biasanya hal ini terjadi ketika seorang tiba-tiba mendapat sesuatu yang baru misalnya, kekayaan, pangkat, kedudukan atau jabatan dsb.

\section{Langkah-langkah Pembinaan Integritas}

Karena terbatasnya kesempatan, maka bagian ini hanya akan mengungkap beberapa catatan yang diharapkan dapat dipertimbangkan sebagai upaya untuk membina dan mempertahankan integritas. Saya katakan beberapa, karena tentu ada banyak cara dan metode yang bisa dikembangkan sesuai dengan situasi dan kondisi serta tekad masing-masing.

\section{Konsep Diri yang Benar}

Yang kita maksudkan dengan konsep diri adalah gambaran diri yang benar atau yang asli atau otentik. Barangbarang tiruan biasanya murah dan yang asli itu mahal. Menurut arti kamus bahwa otentik itu ialah sesuatu yang sesuai dengan apa yang ada atau diakui ada. Dengan kata lain bahwa otentik adalah sesuatu benar sebagaimana adanya.

Bill Hibels menyatakan keyakinannya dengan berkata, "Saya percaya bahwa tantangan terbesar yang menghadang gereja selama dua dasawarsa mendatang adalah penyakit yang merusak kekuatan dan integritas kekristenan tidak otentik". ${ }^{5}$ Kekhawatiran Hibels ini sedang menggejala di mana-mana dan tidak mengenal siapa pun. Memang asli, tetapi palsu. Penawarnya ialah hindari segala kepalsuan dan praktek-praktek kepalsuan.

\section{Kerendahan Hati}

Kerendahan hati adalah suatu kerelaan untuk tidak menggunakan hak yang ada dengan sukarela demi per- timbangan yang arif. Yesus adalah salah satu contohnya (Fil. 2:5-dst).

\section{Keseimbangan}

Saya pernah membaca wawancara seorang terhadap seorang yang telah berusia lanjut, tetapi masih semangat dan tangguh. Ia ditanya "Apa rahasia hidupnya?" Jawabannya singkat, "Saya berusaha hidup seimbang! Seimbang makan, seimbang berpikir, seimbang kerja, seimbang istirahat dst." Artinya memelihara kesadaran diri dalam menghadapi apa saja yang tampaknya berubah dari yang biasa. Jika mesin terlalu panas, matikan sebentar supaya dingin; jika rasanya terlalu capek dan sibuk, ambil saat untuk retreat dst.

\section{Kesederhanaan}

Sederhana bukan semberono dan tidak karuan. Rasul Paulus memberikan nasihat praktis untuk dapat menikmati hidup bersama yang aman dan sejahtera berkata, "Janģanlah kamu memikirkan perkara-perkara yang tinggi, tetapi arahkanlah dirimu pada perkara-perkara yang sederhana" (Rom. 12:16). Belajarlah memadakan apa yang ada padamu.

\section{Kejujuran}

Sebenarnya semua orang tahu apa yang dimaksud dengan kejujuran, karena setiap orang ingin diper-lakukan dengan jujur. Yang penting ialah bahwa kejujuran itu bukan teori yang harus dipelajari dan diajarkan, tetapi sesuatu yang harus dilakukan dan dibuktikan. Apalah artinya jika fasih menghafal ayat-ayat tentang kejujuran, tetapi kejujuran itu hanya sebagai teori belaka.

\section{Penguasaan Diri}

Penguasaan ini adalah pembatasan atau pengekangan keinginan demi sesuatu yang dianggap bernilai lebih baik. 
Penguasaan diri adalah salah satu buahbuah Roh kudus (Gal. 5:23).

\section{Komitmen}

Komitmen adalah sumpah setia terhadap suatu pengakuan. Roy Marciano, seorang petinju yang pernah mengagetkan para pecandu tinju ketika dalam usia 32 tahun saat-saat ia dipuja dan didewakan penggemarnya, tiba-tiba mengundurkan diri dari dunia tinju. Akhirnya ketahuan bahwa ia pernah berjanji kepada kekasihnya bahwa ketika ia mencapai batas bayaran sekian dolar ia akan berhenti, dan benar ketika terbayang jutaan dolar di depannya ia berhenti karena komitmen. Yang menjadi masalah di sini ialah banyak orang yang ketika hari mulai panas, malah menjadi seperti kacang lupa akan kulitnya. Salah satu rahasia untuk mempertahankan integritas diri ialah tetap pada komitmen, seperti Daniel mempunyai komitmen untuk tidak menajiskan dirinya dengan santapan-santapan raja yang menggiurkan.

\section{Kewaspadaan}

Jika diamati kasus-kasus yang sering menggoncangkan hati dari tumbangnya tokoh-tokoh yang biasa disanjung, maka akan dijumpai akar masalahnya ialah karena kekurang hatihatian. Petrus memberikan naśehat yang sangat strategis dengan mengatakan: "Sadarlah dan berjaga-jagalah. Lawanmu, si iblis, berjalan keliling sama seperti singa yang mengaum-ngaum dan mencari orang yang dapat ditelainya." (I Pet. 5:8).

\section{Belajar pada Yesus}

Yesus adalah manusia sempurna dengan integritas tanpa cacat meskipun Ia juga pernah dicobai dan dalam keadaan manusia Ia merasakan pengalaman-pengalaman manusia seperti kita. Mari kita terus-menerus belajar kepada Yesus. Belajar rendah hati seperti Yesus; belajar menangis seperti Yesus; belajar ramah seperti Yesus; belajar lapar seperti Yesus; belajar berkorban seperti Yesus; belajar setia sampai mati seperti Yesus

\section{Penutup}

Integritas adalah wujud dan kualitas kehidupan yang sangat penting dan menentukan jatuh bangunnya seseorang. Segala karya dan prestasi ditentukan olehnya sehingga perlu dipelihara dan dibina dengan sebaikbaiknya. Seorang pelayan ideal adalah seorang pelayan yang memiliki karakterkarakter luhur dan mulia, sehingga ia berwibawa dan menjadi saluran berkat Allah bagi orang lain. Gereja sedang merindukan pelayan-pelayan yang mempunyai integritas diri untuk menjadi teladan dalam pengabdian dan ketaatan kepada Tuhan. Selamat melayani...!

\section{Endnotes:}

'Kamus Besar Bahasa Indonesia s.v. "integritas"

2 John C. Maxweel, Mengembangkan Kepemimpinan di dalam Diri Anda, (Jakarta: binarupa Aksara, 1955), 38.

${ }^{3}$ Ibid, 37-50

${ }^{4}$ Laurie Beth Jones, Yesus Chief Executif Officer, (Jakarta: Penerbit Mitra Utama, 1977), hal. 7.

${ }^{5}$ Bill Hibels, Jujur terhadap Allah, (Jogyakrta: Yayasan Andi Offset, 1999), hal. 9. 